REGULAR ARTICLE

\title{
MAXIMIZING THE SHELF LIFE OF MONOXENICALLY PRODUCED CARRIER-BASED AM FUNGAL BIO-INOCULA FOR MAINTAINING ITS LONG-TERM VIABILITY
}

\author{
RODRIGUES KIM MARIA*, RODRIGUES BERNARD FELINOV
}

Department of Botany, Goa University, Taleigao Plateau, Goa 403206, India

\begin{abstract}
Arbuscular mycorrhizal (AM) fungi are often applied as bio-inoculants due to their plant growth promoting benefits. The objectives of the present work were to maximize the shelf life of monoxenically produced carrier-based AM fungal bio-inocula of Rhizoglomus intraradices and Funneliformis mosseae. Shelf life of in vitro produced inoculum was studied by assessing the infectivity potential of in vitro produced inocula in an optimum carrier formulation (vermiculite: cow dung powder: wood powder: wood ash in the ratio of 20:8:2:1) during storage at three different temperatures viz., $4{ }^{\circ} \mathrm{C}, 25^{\circ} \mathrm{C}$ and room temperature (RT). The re-germination potential of in vitro produced spores from carrier-based inocula to in vitro conditions was also examined. The in vitro produced inocula stored at $25{ }^{\circ} \mathrm{C}$ remained viable up to 6 mo in the organic carrier formulation. $100 \%$ germination was recorded when the spores of both AM species were cultured back to in vitro conditions indicating high viability, and efficiency of the carrier formulation in maintaining vigour of in vitro produced propagules.
\end{abstract}

Keywords: Rhizoglomus intraradices, Funneliformis mosseae, Carrier-based bio-inocula, Shelf life

\section{INTRODUCTION}

Arbuscular mycorrhizal (AM) fungi are biotrophic symbionts that provide beneficial effects to a wide range of host plant species [1]. They represent a key link between soil and plants, and have gained a growing attention as ecosystem engineers and bio-inoculants [2-4]. Currently, AM fungal bio-inoculants are being used in the agricultural practices for reclamation of stress affected soils and also as an alternative for chemical fertilizers [5, 6]. Bio-inoculants are usually prepared as carrier-based inoculants containing effective micro-organisms [7-9]. AM fungal inoculum being commercially available in many forms [1013]. Over the last decades, a considerable effort has been made to develop suitable carrier formulations of highly infective and efficient AM fungal propagules [3]. Rodrigues and Rodrigues [14] developed an optimum carrier formulation that is able to maintain high inoculum infectivity and efficiency of the in vitro produced isolates of Rhizoglomus intraradices and Funneliformis mosseae. Considering the carrier formulation (treatment 5 consisting of vermiculite, cow dung powder, wood powder, and wood ash in the ratio 20:8:2:1). The type of carrier materials used, their physico-chemical properties and the proportions incorporated proved that the organic carrier formulation prepared is suitable for mass production of in vitro produced AM fungal inocula. However, for any bioinoculant to be used within agronomical practices, the carrier formulation should primarily retain the viability of a large population of the incorporated inoculant microorganism during long-term storage period [15]. A good carrier should also ensure sufficient shelf life of at least 2-3 mo at room temperature [16]. Non-availability of good quality and appropriate carrier materials can affect shelf life of the beneficial microbial inoculants. Drying process, moisture content, storage conditions plus storage temperature are also important determinants of the shelf life of microbial inoculants or formulations and can affect their activity pre-or post-application [17-21].

Efficient storage of bio-inoculants is a major constraint in the production of AM inoculants [22]. In general, fungi can be preserved and stored as per three procedures viz., continuous growth method, drying by air or with silica gel, and reduction of available water in the cells, which results in suspension of metabolism [23]. Monoxenic cultivation of AM fungi is the best method for production of contaminant-free inocula [24]. However, sub-cultivation is being practiced for the maintenance [25-27] and contaminations risk is common problem [25]. Moreover, sub-cultivation is difficult or genetic variation may occur [28] and, genetic and physiological changes overtime cannot be prevented [29, 25, 30]. Thus, a method to maintain the viability, purity and stability of monoxenically produced AM fungal isolates over longterm storage periods is needed.

\section{Received 13 February 2018; Accepted 19 April 2018 \\ *Corresponding Author \\ Rodrigues Kim Maria \\ Department of Botany, Goa University, Taleigao Plateau, Goa 403206 India \\ Email: botany.kim@unigoa.ac.in}

(T) This article is open access and licensed under the terms of the Creative Commons Attribution License (http://creativecommons.org/licenses/by/4.o/) which permits unrestricted, use, distribution and reproduction in any medium, or format for any purpose, even commercially provided the work is properly cited. Attribution - You must give appropriate credit, provide a link to the license, and indicate if changes were made. 
The present study is aimed at maximizing the shelf life of monoxenically produced carrier-based AM fungal bioinocula by assessment of infectivity potential of in vitro produced inocula in an optimum carrier formulation (vermiculite: cow dung powder: wood powder: wood ash in the ratio of 20:8:2:1) during storage at different temperatures $\left(4^{\circ} \mathrm{C}, 25{ }^{\circ} \mathrm{C}\right.$ and room temperature), and by assessment of re-germination potential of in vitro produced spores from carrier-based inocula to in vitro conditions.

\section{MATERIALS AND METHODS}

Assessment of infectivity potential of in vitro produced inocula in carrier formulation during storage at different temperatures

\section{AM fungal inocula}

The indigenous AM fungal isolates (Rhizoglomus intraradices and Funneliformis mosseae) obtained from Goa University Arbuscular Mycorrhizal Culture Collection (GUAMCC) were used for the present study. Monoxenic cultures were established by the association of disinfected spores [31] with transformed roots of chicory (Cichorium intybus L.) or linum (Linum usitatissimum L.) on modified Strullu-Romand (MSR) medium [27]. The Petri-plates were incubated in an inverted position in the dark at $27{ }^{\circ} \mathrm{C}$. Sporulation in monoxenic cultures of $R$. intraradices was observed 18-20 d after association with transformed chicory roots and continued up to 7 mo. In monoxenic cultures of $F$. mosseae, sporulation was observed 15-20 d after association with transformed linum roots and continued up to 7 mo. The monoxenically cultured spores were isolated by solubilization of the MSR medium [32] and used for storage studies.

\section{Storage of inocula}

The inocula of the AM species $R$. intraradices and $F$. mosseae containing colonized transformed root fragments with extra-radical hyphae and spores was mixed along with optimum carrier formulation consisting of vermiculite, cow dung powder, wood powder and wood ash in proportion of 20:8:2:1 (64.51\%: 25.80\%: 6.45\%: $3.22 \%$ ) and stored at three different temperatures viz., $4{ }^{\circ} \mathrm{C}, 25{ }^{\circ} \mathrm{C}$ and room temperature $\left(28-30^{\circ} \mathrm{C}\right)$ to assess the viability. Inocula of the two AM fungal species were stored separately in zip-loc polythene bags. Care was taken to ensure the absence of free moisture on the inside of the bags.

\section{Infectivity tests}

Infectivity tests of the inocula were carried out at the end of every $2^{\text {nd }}$ month after storage for 2,4 , and $6 \mathrm{mo}$, by incorporating $10 \mathrm{~g}$ of the carrier-based inoculum containing approximately 1200 infective propagules into $500 \mathrm{~g}$ of sterilized sand in $15 \mathrm{~cm}$ plastic pots and using cuttings of Plectranthus scutellarioides (L.) R. Br. (Coleus) (Lamiaceae) as host plant. Each treatment consisted of six replicates. The pots were maintained for a period of 3 mo in the shade net of Department of Botany, Goa University, under natural conditions of light, temperature and humidity (4000-6000 lux light intensity, $32{ }^{\circ} \mathrm{C} / 25{ }^{\circ} \mathrm{C}$ day/night, $\mathrm{RH}$ 80-90 \%) for the establishment of AM symbiosis.

\section{Processing of root segments for AM fungal colonization}

Assessment of AM colonization in roots of $P$. scutellarioides was carried out by using Trypan blue staining technique after 3 mo of growth [33]. The infectivity of the stored inocula was ascertained by the same procedure at every $2^{\text {nd }}$ month up to the $6^{\text {th }}$ month.

\section{Estimation of percent root colonization}

Estimation of percent root colonization by AM fungi was carried out using root slide method [34].

Percent colonization $=$ number of root segments colonized $\div$ total number of root segments observed $\times 100$

\section{Statistical analysis}

The experimental data was subjected to one-way analysis of variance (ANOVA) followed by Tukey post-Hoc pairwise comparison test. Statistical Package for Social Sciences (SPSS) (ver. 22.0 Armonk, NY: IBM Corp.) was used for all statistical analyses.

\section{Re-germination potential of in vitro produced spores from carrier-based inocula to in vitro conditions}

\section{Extraction of AM fungal propagules}

Extraction of AM propagules (spores and colonized root fragments) from the carrier formulation was carried out by wet sieving and decanting technique [35].

\section{AM fungal propagule disinfection process}

The disinfection process was modified from Mosse [36], Mertz et al. [37], Daniels and Menge [38], and Bécard and Fortin [31]. Isolated propagules were first rinsed twice with sterilized distilled water after which they were disinfected. The propagules were then disinfected with 250-400 $\mu \mathrm{l}$ sodium hypochlorite $(\mathrm{NaClO})$ for 3-5 min. After disinfection, the propagules were rinsed three times with sterilized distilled water and treated with antibiotic solution (Streptomycin $0.02 \%+$ Gentamycin $0.01 \%$ ) for $10 \mathrm{~min}$.

\section{Germination of disinfected propagules}

Disinfected AM propagules were then inoculated on MSR media [27] minus sucrose and Petri plates were incubated in the dark at $27^{\circ} \mathrm{C}$ in an inverted position.

\section{RESULTS} Infectivity potential of in vitro prepared inocula in
carrier formulation during storage

Upon storage the infectivity potential of in vitro prepared inocula of both the AM fungal species viz., R. intraradices and $F$. mosseae were observed to be optimum at $25{ }^{\circ} \mathrm{C}$ when compared to other storage temperatures $\left(4^{\circ} \mathrm{C}\right.$ and room temperature) used in the study. AM fungal colonization levels ranged from $89-93 \%$ for $R$. intraradices and $85-90 \%$ for $F$. mosseae when stored at $25{ }^{\circ} \mathrm{C}$ indicating that the inocula did not lose infectivity potential even after 6 mo of storage. ANOVA comparing the effect of storage at the three different temperatures on percent colonization by in vitro prepared inocula in carrier formulation revealed that percent colonization was significantly greater in propagules stored at $25{ }^{\circ} \mathrm{C}$ (fig. 1, table 1).

\section{Re-germination potential of in vitro produced spores from carrier-based inocula to in vitro conditions}

It was observed that spores of $R$. intraradices germinated 2-10 d while spores of $F$. mosseae germinated 10-15 d, after plating (fig. 2 a-d), and 100\% germination was recorded indicating that spores of both the AM species retained viability to re-germinate when cultured back using in vitro conditions. 


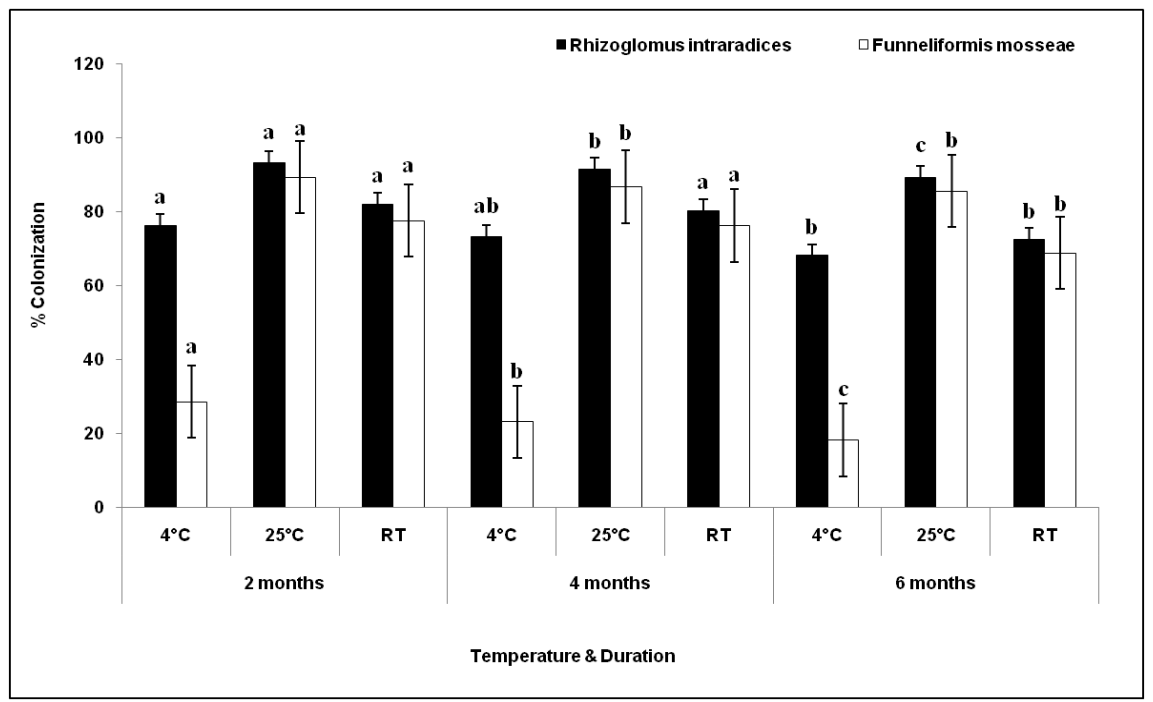

Fig. 1: Percent root colonization in Plectranthus scutellarioides (L.) R. Br. by in vitro produced AM fungal inocula stored at different temperatures

Legend: All values are means of six replicates \pm standard deviation. Bars not sharing the same letters are significantly different $(P \leq 0.05) . \mathrm{RT}=$ Room Temperature $\left(28-30^{\circ} \mathrm{C}\right)$

Table 1: Analysis of variance for percent colonization of Plectranthus scutellarioides (L.) R. Br. inoculated with in vitro produced AM fungal inocula stored at different temperatures

\begin{tabular}{|c|c|c|c|c|c|c|c|c|c|c|}
\hline \multirow[t]{2}{*}{ Temperature } & \multicolumn{6}{|c|}{ Rhizoglomus intraradices } & \multicolumn{4}{|c|}{ Funneliformis mosseae } \\
\hline & Source & $d f$ & SS & MS & $\boldsymbol{F}$ & $\boldsymbol{P}$ & SS & MS & $\boldsymbol{F}$ & $\boldsymbol{P}$ \\
\hline \multirow[t]{3}{*}{$4^{\circ} \mathrm{C}$} & Between & 2 & 203.473 & 101.736 & 5.971 & $0.02 *$ & 319.062 & $159 \cdot 531$ & 4.455 & $0.03^{*}$ \\
\hline & Within & 15 & 218.938 & 17.039 & & & 537.104 & 35.807 & & \\
\hline & Total & 17 & 422.411 & & & & 856.167 & & & \\
\hline \multirow[t]{3}{*}{$25{ }^{\circ} \mathrm{C}$} & Between & 2 & 49.681 & 24.840 & 18.849 & $0.00^{* * *}$ & 43.942 & 21.971 & 16.118 & $0.00^{* *}$ \\
\hline & Within & 15 & 19.768 & 1.318 & & & 20.447 & 1.363 & & \\
\hline & Total & 17 & 69.449 & & & & 64.388 & & & \\
\hline \multirow[t]{3}{*}{ RT } & Between & 2 & 311.924 & 155.962 & 16.967 & $0.00^{* * *}$ & 265.577 & 132.789 & $5 \cdot 324$ & $0.01^{* *}$ \\
\hline & Within & 15 & 137.881 & 9.192 & & & 374.130 & 24.942 & & \\
\hline & Total & 17 & 449.805 & & & & 639.708 & & & \\
\hline
\end{tabular}

Legend: $d f$ degrees of freedom, $S S$ sum of squares, $M S$ mean square; ${ }^{* *}$ Significant at $P \leq 0.01$ and $P \leq 0.05$, ${ }^{*}$ Significant at $P \leq$ o.05; RT = Room Temperature $\left(28-30^{\circ} \mathrm{C}\right)$.
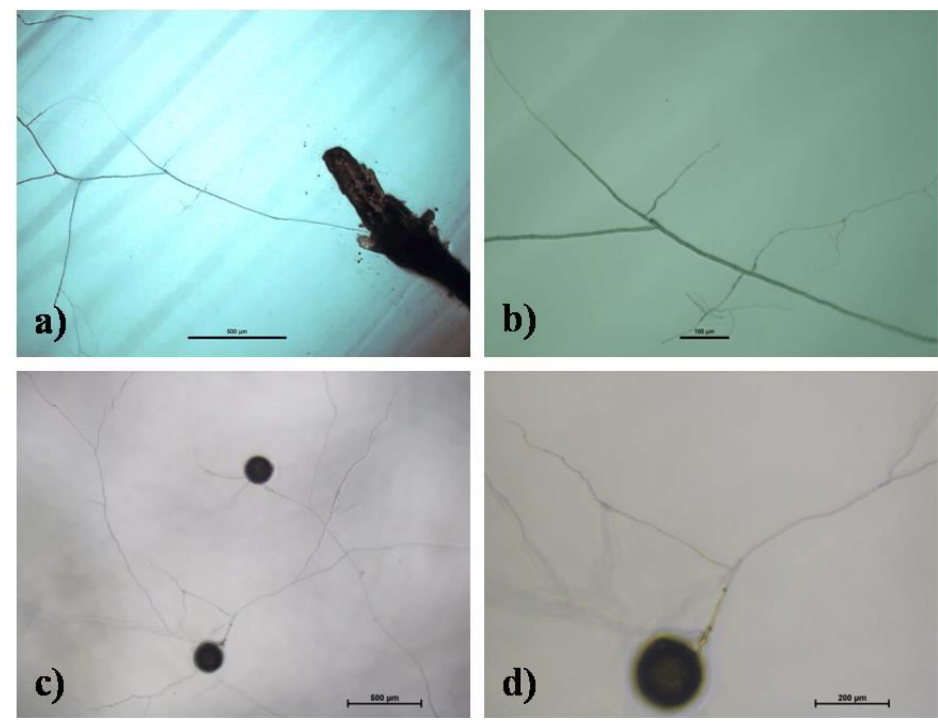

Fig. 2: Re-germination potential of in vitro produced spores from carrier-based inocula to in vitro conditions. a) In vitro germination of colonized root fragment of Rhizoglomus intraradices; b) Enlarged view of branching of hypha emerging from colonized root fragment of Rhizoglomus intraradices; c) In vitro spore germination of Funneliformis mosseae; d) Enlarged view of in vitro spore germination of Funneliformis mosseae 


\section{DISCUSSION}

In the present study, in vitro prepared inocula in carrier formulation were tested for their infectivity potential during storage. Upon storage the infectivity potential of in vitro prepared inocula of both the AM fungal species viz., $R$. intraradices and $F$. mosseae were observed to be optimum at $25{ }^{\circ} \mathrm{C}$ compared to other storage temperatures used in the study. AM fungal colonization levels of 89-93\% in $R$. intraradices and $85-90 \%$ in $F$. mosseae were recorded at $25{ }^{\circ} \mathrm{C}$ indicating that the inocula did not lose infectivity potential even after 6 mo of storage. Louis and Lim [39] showed that the germination ability of a tropical isolate of $R$. clarum was enhanced after 3-6 mo of dry storage at $25-30{ }^{\circ} \mathrm{C}$. Kuszala and Gianinazzi-Pearson [40] preserved propagules of AM fungal isolates belonging to Glomus, Acaulospora, Gigaspora, Scutellospora extracted from 6-11 mo old pot cultures, in osmosed water at $4{ }^{\circ} \mathrm{C}$, at ambient temperature, at $+27{ }^{\circ} \mathrm{C}$ or at $+37{ }^{\circ} \mathrm{C}$. AM fungal propagules are commonly stored at $4-5{ }^{\circ} \mathrm{C}$ in dried pot culture soil [41]. At the International Culture Collection of (Vesicular) Arbuscular Mycorrhizal Fungi (INVAM), most of the AM fungal propagules produced in pot cultures are stored in dried soil or substrate at $4{ }^{\circ} \mathrm{C}$ for different time periods depending on the genus. A number of studies have demonstrated that the preservation of $\mathrm{AM}$ fungal propagules in soil, saturated salt solutions, alginate beads and osmosed water by drying or cold storage was optimum at $4{ }^{\circ} \mathrm{C}$ [42-47]. This was, however, contrary to our findings. Our results however indicate that $25{ }^{\circ} \mathrm{C}$ was optimum storage temperature for the carrier-based AM fungal inocula which can be considered as a feasible option.

It has been reported that the higher maintenance of viability of $\mathrm{AM}$ fungal inocula in substrates containing vermiculite due to better aeration and water retention capacity [48]. The viability and efficiency of the inocula can be maintained for several months at $20-25{ }^{\circ} \mathrm{C}$, but the inocula should be kept in its packaging and must be partially dried [49]. It is important to stress that the inocula must be dried before storage $[50,51]$. The viability of inocula will decrease under extended storage under humid substrate [52]. Earlier reports showed that the sources of inoculum stored in moistened vermiculite maintained its infective potential only for $2 \mathrm{mo}[53,54]$.

The AM species used in our study viz., $R$. intraradices and $F$. mosseae occur in a wide range of biomes and adapted to specific environment, and hence may exhibit viability in a range of temperatures. Our study, revealed that spores of $R$. intraradices germinated 2-10 d while spores of $F$. mosseae germinated 10-15 d after plating, with no spore dormancy indicating that spores of both the AM species were viable and re-germinating when cultured back to in vitro conditions as well as signifying the efficacy of the carrier formulation in maintaining the vigour of in vitro produced spores.

\section{CONCLUSION}

The results obtained in our study are very promising from the point of view of a possible commercial production of AM fungal inoculants. The in vitro produced inocula stored at $25{ }^{\circ} \mathrm{C}$ remained viable up to 6 mo in the organic carrier formulation composed of vermiculite, cow dung powder, wood powder and wood ash, therefore being recommended for use as bio-inoculants. However, further experiments may be needed to test the suitability of the carrier formulation developed for long-term preservation and reproducibility in other AM fungal species.

\section{ACKNOWLEDGEMENT}

The first author gratefully acknowledges the financial assistance received from Innovation in Science Pursuit for Inspired Research (INSPIRE) programme, Department of Science and Technology (DST), Government of India, New Delhi under Grant Dy. No. C/3807/IFD/2015-16 to carry out this study.

\section{REFERENCES}

1. Adholeya A, Tiwari P, Singh R. Large-scale inoculum production of arbuscular mycorrhizal fungi on root organs and inoculation strategies. In: Declerck S., Strullu D. G., Fortin J. A. (eds.). 2005; In vitro culture of mycorrhizas. Springer-Verlag, Berlin, Heidelberg, Germany, pp: 315-338.

2. Gianinazzi S, Trouvelot A, Gianinazzi-Pearson V. Role and use of mycorrhizas in horticultural crop production. Adv. Hortic. Sci., 1990;4:25-30.

3. Gianinazzi S, Vosatka M. Inoculum of arbuscular mycorrhizal fungi for production systems, science meets business. Can. J. Bot., 2004;82:1264-1271.

4. Fitter AH, Helgason T, Hodge A. Nutritional exchanges in the arbuscular mycorrhizal symbiosis: implications for sustainable agriculture. Fungal Biol. Rev., 2011;25:68-72.

5. Gianinazzi S, Schüepp H, Barea JM, Haselwandter K. Mycorrhizal technology in agriculture: from genes to bioproducts. Birkhauser, Basel, Switzerland; 2002.

6. Johansson JF, Paul LR, Finlay RD. Microbial interactions in the mycorrhizosphere and their significance for sustainable agriculture. FEMS Microbiol. Ecol., 2004;48:1-13. DOI: 10.1016/j. femsec.2003.11.012.

7. Accinelli C, Ludovica SM, Abbas HK, Zablotowicz RM, Wilkinson JR. Use of a granular bioplastic formulation for carrying conidia of a non-aflatoxigenic strain of Aspergillus flavus. Bioresour. Technol., 2009;100:3997-4004.

8. Malusá E, Sas-Paszt L, Ciesielska J. Technologies for beneficial microorganisms inocula used as biofertilizers. Sci. World J., 2012;2012:491206.

9. Smith RS. Legume inoculant formulation and application. Can. J. Microbiol., 1992;38: 485-492.

10. Smith RS. Inoculant formulations and applications to meet changing needs. In: Tikhonovich I. A., Provorov N. A., Romanov V. I., Newton W. E. (eds.). 1995; Nitrogen Fixation: Fundamentals and Applications. Dodrecht, The Netherlands: Kluwer Academic, pp: 653-657.

11. Corich V, Bosco E, Giacomini A, Basaglia M, Squartini A, Nuti MP. Fate of genetically modified Rhizobium leguminosarum biovar viciae during long-term storage of commercial inoculants. J. Appl. Bacteriol., 1996;81: 319-328.

12. van Elsas JD, Heijnen CE. Methods for the introduction of bacteria into soil: a review. Biol. Fert. Soils, 1990;10: 127-133.

13. Douds DD Jr, Nagahashi G, Hepperly PR. On-farm production of inoculum of indigenous arbuscular mycorrhizal fungi and assessment of diluents of compost for inoculum production. Bioresour. Technol., 2010;101:2326-2330.

14. Rodrigues KM, Rodrigues BF. Development of carrier based in vitro produced arbuscular mycorrhizal (AM) fungal inocula for organic agriculture. Annals of Advanced Agricultural Sciences. 2017;1: 26-37.

15. Malusá E, Vassilev N. A contribution to set a legal framework for biofertilisers. Appl. Microbiol. Biotechnol., 2014;98: 6599-6607. 
16. Herrmann L, Lesueur D. Challenges of formulation and quality of biofertilizers for successful inoculation. Appl. Microbiol. Biotechnol., 2013;97: 8859-8873.

17. Connick WJ, Daigle DJ, Boyette CD, Williams KS, Vinyard BT, Quimby PC Jr. Water activity and other factors that affect the viability of Colletotrichum truncatum conidia in wheat flour-kaolin granules ('Pesta'). Biocontrol Sci. Techn., 1996;6:277-284.

18. Kannaiyan S. Biofertilizer technology and quality control. Publication directorate, TNAU, Coimbatore, India; 2000, pp: 256.

19. Larena I, De Cal A, Liñán M, Melgarejo P. Drying of Epicoccum nigrum conidia for obtaining a shelf-stable biological product against brown rot disease. J. Appl. Microbiol., 2003;94:508-514.

20. Hong TD, Edgington S, Ellis RH, de Muro MA, Moore D. Saturated salt solutions for humidity control and the survival of dry powder and oil formulations of Beauveria bassiana conidia. J. Invertebr. Pathol., 2005;89:136-143.

21. Friesen T, Holloway G, Hill G, Pugsley T. Effect of conditions and protectants on the survival of Penicillium bilaiae during storage. Biocontrol Sci. Techn., 2006;16:89-98.

22. Arora NK, Maheshwari DK, Khare E. PGPR: Constraints in Bioformulation, Commercialization and Future Strategies. In: Maheshwari D. K. (ed.). 2010; Bacteria and Plant Health. Springer, pp: 97-116.

23. Smith D, Onions AHS. IMI Technical Handbooks 2: the preservation and maintenance of living fungi, $2^{\text {nd }}$ ed. CAB International, Wallingford; 1994.

24. Ijdo M, Cranenbrouck S, Declerck S. Methods for large-scale production of AM fungi: past, present, and future. Mycorrhiza. 2011;21:1-16.

25. Plenchette C, Declerck S, Diop TA, Strullu DG. Infectivity of monoxenic subcultures of the arbuscular mycorrhizal fungus Glomus versiforme associated with $\mathrm{Ri}$ T-DNA transformed carrot root. Appl. Microbiol. Biotechnol., 1996;46:545-548.

26. Strullu DG, Diop TA, Plenchette C. Realisation de collections in vitro de Glomus intraradices (Schenck et Smith) et de Glomus versiforme (Karsten et Berch) et proposition d'un cycle de developpement. C. R. Acad. Sci., 1997;320:41-47.

27. Declerck S, Strullu DG, Plenchette C. Monoxenic culture of the intraradical forms of Glomus sp. isolated from a tropical ecosystem: a proposed methodology for germplasm collection. Mycologia. 1998;90:579-585.

28. Declerck S, Strullu DG, Fortin JA. In vitro culture of mycorrhizas. Springer-Verlag, Berlin, Heidelberg, Germany; 2005.

29. Douds DD, Schenck NC. Cryopreservation of spores of vesicular arbuscular mycorrhizal fungi. New Phytol., 1990;115:667-674.

30. Declerck S, Van Coppenolle A. Cryopreservation of entrapped monoxenically produced spores of an arbuscular mycorrhizal fungus. New Phytol., 2000;148:169-176.

31. Bécard G, Fortin JA. Early events of vesiculararbuscular mycorrhiza formation on Ri T-DNA transformed roots. New Phytol., 1988;108:211-218.

32. Cranenbrouck S, Voets L, Bivort C, Renard L, Strullu DG, Declerck S. Methodologies for in vitro cultivation of arbuscular mycorrhizal fungi with root-organs. In: Declerck S., Strullu D. G., Fortin J. A. (eds.). 2005; In vitro culture of mycorrhizas. Springer-Verlag, pp: 341-375.
33. Phillips JM, Hayman DS. Improved procedures for clearing roots and staining parasitic and vesicular arbuscular mycorrhizal fungi for rapid assessment of infection. Trans. Br. Mycol. Soc., 1970;55:158-161.

34. Read DJ, Koucheki HK, Hodgson J. Vesiculararbuscular mycorrhiza in natural vegetation systems. I. The occurrence of infection. New Phytol., 1976;77: 641-653.

35. Gerdemann JW, Nicolson TH. Spores of mycorrhizal Endogone species extracted from soil by wet sieving and decanting. Trans. Br. Mycol. Soc., 1963;46: 235-244.

36. Mosse B. The regular germination of resting spores and some observations on the growth requirements of an Endogone sp. causing vesicular-arbuscular mycorrhiza. Trans. Br. Mycol. Soc., 1959;42:273-286.

37. Mertz SM Jr, Heithaus JJ, Bush RL. Mass production of axenic spores of the endomycorrhizal fungus Gigaspora margarita. Trans. Br. Mycol. Soc., 1979;72:167-169.

38. Daniels BA, Menge JA. Evaluation of the commercial potential of the vesicular-arbuscular mycorrhizal fungus Glomus epigaeus. New Phytol., 1981;87:345-354.

39. Louis I, Lim G. Effect of storage of inoculum on spore germination of a tropical isolate of Glomus clarum. Mycologia. 1988;80:157-161.

40. Kuszala C, Gianinazzi-Pearson V. Méthodes de conservation hors sol des champignons mycorhizogènes à arbuscules et effets de la dessiccation et de la température sur leur survie. Cah. Tech. Inra., 2011;73:5-23.

41. Siqueira JD, Sylvia DM, Gibson J, Hubell DH. Spores, germination, and germ tubes of vesicular-arbuscular mycorrhizal fungi. Can. J. Microbiol., 1985;31:965-972.

42. Ferguson JJ, Woodhead SH. Production of endomycorrhizal inoculum. A. Increase and maintenance of vesicular-arbuscular mycorrhizal fungi. In: Schenck N. C. (ed.). 1982;Methods and principles of mycorrhizal research. The American Phytopathological Society, St Paul, Minnesota, pp: 47-54.

43. Mugnier J, Mosse B. Spore germination and viability of a vesicular arbuscular mycorrhizal fungus, Glomus mosseae. Trans. Br. Mycol. Soc., 1987;88:411-413.

44. Tommerup IC. Long-term preservation by L-drying and storage of vesicular-arbuscular mycorrhizal fungi. Trans. Br. Mycol. Soc., 1988;90:585-591.

45. Strullu DG, Plenchette C. The entrapment of Glomus sp. in alginate beads and their use as root inoculum. Mycol. Res., 1991;95:1194-1196.

46. Kuszala C, Gianinazzi S, Gianinazzi-Pearson V. Storage conditions for the long-term survival of AM fungal propagules in wet sieved soil fractions. Symbiosis. 2001;30:287-299.

47. Wagner SC, Skipper HD, Walley F, Bridges WB Jr. Long-term survival of Glomus claroideum propagules from soil pot cultures under simulated conditions. Mycologia. 2001;93: 815-820.

48. Santana de AS, Cavalcante UMT, Sampaio Barreto de Sa EV, Maia LC. Production, storage and costs of inoculum of arbuscular mycorrhizal fungi (AMF). Braz. J. Bot., 2014;37: 159-165.

49. Berruti A, Borriello R, Orgiazzi A, Barbera AC, Lumini E, Bianciotto V. Arbuscular mycorrhizal fungi and their value for ecosystem management. In: Grillo $\mathrm{O}$. (ed.). 2014; Biodiversity-the dynamic balance of the planet. InTech, pp: 159-191.

50. Hung LL, Sylvia DM. Production of vesiculararbuscular mycorrhizal fungus inoculum in aeroponic culture. Appl. Environ. Microbiol., 1988;54:353-357. 
51. Sylvia DM. Vesicular-arbuscular mycorrhizal fungi. In: Mickelson S. H., Bigham J. M. (eds.). 1994; Methods of soil analysis, part 2. Microbiological and biochemical properties. SSA Book Series 5, pp: 351-378.

52. Sylvia DM, Jarstfer AG. Sheared-root inocula of vesicular-arbuscular mycorrhizal fungi. Appl. Environ. Microbiol., 1992;58:229-232.
53. Sieverding E. Vesicular-arbuscular mycorrhizal management in tropical agrosystems. Deutsche Gesellschaft für Technische Zusammenarbeit (GTZ), Eschborn; 1991.

54. Lalaymia I, Cranenbrouck S, Declerck S. Maintenance and preservation of ectomycorrhizal and arbuscular mycorrhizal fungi. Mycorrhiza. 2014;24:323-337. 